\title{
PETROGRAPHY AND MINERAL CHEMISTRY OF THE MCLEAN KIMBERLITE, LAKE TIMISKAMING, ONTARIO
}

\author{
Sherri Hodder \\ University of Calgary, Canada
}

\begin{abstract}
A petrological investigation of the McLean (141.9 Ma) pipe in the Lake Timiskaming kimberlite field in Ontario, Canada was undertaken based on 1999 GSC samples from surface pits and core drilling. Core to rim zoning trends in phlogopite and spinel, and mineral assemblages of the McLean kimberlite allowed it to be classified as an archetypal (Group I) kimberlite. The kimberlite is a multiphase intrusion, exhibiting both diatreme and hypabyssal facies kimberlite which are variably altered. The McLean is capped by a hypabyssal aphanitic kimberlite which was observed to be in contact with the adjacent sedimentary rocks in a surface trench.
\end{abstract}

The McLean aphanitic kimberlite exhibits typical Group I kimberlite mineralogy, but with unique textures. The fine-grained nature of the pipe dictated the use of both the scanning electron microscope and the electron microprobe in the analyses. The chemistry of selected macrocryst, microcryst and groundmass minerals were analyzed, evaluated and compared with Canadian and world kimberlite examples. The results of this study indicate that despite its fine-grained nature there is little chemical variation within the McLean kimberlite minerals in comparison to other kimberlite. In addition to this, there was little progression of REE's from the kimberlite into the country rock in analyses across the contact zone.

Keywords: Kimberlite; aphanitic; mineralogy; Canada.

\section{INTRODUCTION}

The McLean kimberlite 141.9 Ma, (Heaman and Kjarsgaard, 2000) is located in the Lake Timiskaming kimberlite field of Ontario, Canada. Drillcore observations indicate variably altered diatreme and hypabyssal facies kimberlite to end of hole at $92.3 \mathrm{~m}$. The pipe is capped at the surface by hypabyssal facies aphanitic kimberlite $(<5$ vol. $\%$ clasts $>4 \mathrm{~mm})$. The McLean kimberlite was observed to be in contact with the adjacent sedimentary rocks of the Firstbrook Member of the Gowganda Formation in a surface trench (McClenaghan et al., 1999). A systematic sampling and chemical analyses across this "contact zone" was undertaken to determine if progression of REE minerals (or other trace minerals) occurs across this kimberlite contact (Hodder, 2002).

The fine-grained nature of the pipe required the use of normal petrographic methods in conjunction with scanning electron microscopy (SEM). The mineral chemistry of selected macrocryst, microcryst and groundmass minerals (olivine, phlogopite, ilmenite, spinel, apatite and perovskite) in the McLean kimberlite was determined by electron microprobe. Complete petrographic descriptions and mineral chemistry data regarding the McLean kimberlite and McLeanFirstbrook contact are available in Hodder (2002).

\section{PETROGRAPHIC OBSERVATIONS}

\section{OLIVINE}

Olivine occurs as well-rounded microphenocrysts and subhedral to rounded microcrysts $(0.1$ to $0.5 \mathrm{~mm})$ with very few macrocrysts $(0.5$ to $10 \mathrm{~mm})$ and rare megacrysts $(>1.0 \mathrm{~cm})$ (Hodder, 2002). It is commonly altered with complex internal zoning, irregular extinction and serpentine rims (iddingsite and rutile) surrounding grains. Olivine are typically mantled by Fe-rich atoll-spinels, perovskite and monticellite. Altered olivine microcrysts are common near the contact zone and in surficial samples. Pseudomorphs of olivine are common near and within the contact zone. Few olivine grains near the contact zone maintain olivine cores. Typically these grains show complex serpentinization with calcite crystals in cores and associated with irregular masses of calcite (barite/celestite) in the groundmass.

\section{PHLOGOPITE}

The pipe contains mica of the phlogopite to kinoshitalite series (commonly $<50 \mu \mathrm{m}$ ). Phlogopite exhibits several habits that may be attributed to more than one generation of phlogopite present in the multiphase pipe. Secondary micas are generally larger and located near veins or calcite segregations. Sievetextured phlogopite- kinoshitalite crystals enclose ilmenite, spinel, and perovskite. Groundmass 
phlogopite-kinoshitalite grains are typically surrounded by skeletal apatite, atoll-spinel. Larger phlogopite grains located are associated with small irregular segregations $(<1.0 \mathrm{~mm})$ of calcite. Phlogopite was not observed in the contact zone area.

\section{ILMENITE}

The volume, texture and habit of ilmenite vary with depth throughout the McLean kimberlite. Ilmenite microcrysts and macrocrystic fragments occur as euhedral, anhedral to subhedral crystals with corroded or rounded grain boundaries. Microcrystic grains contain complex zones extending from core to rim that may contain any, or all, of the following; leucoxene, magnetite and rutile-iddingsite or lizardite-chrysotile, often associated with segregations or crystals of calcite. These grains contain few inclusions of spinel and/or perovskite. Groundmass ilmenites contain intergrowths (co-precipitation) of spinel-perovskite, rutile ( \pm pyroxene) within grains. Geikielite rims surrounding groundmass (or microcrystic) ilmenite display 'frayed' or 'cracked' margins with a core-rim zonation from ilmenite to geikielite. Rutile is associated with groundmass ilmenite occurs at grain margins typically forming clusters of fine-grained $(<15 \mu \mathrm{m})$ radiating crystals. Groundmass ilmenite in the Firstbrook Member are smaller than those within the kimberlite. These grains typically exhibit exsolution lamellae of hematite and associated with small veinlets of calcite (with barite/celestite).

\section{SPINEL}

Spinel group minerals are pervasive in the McLean kimberlite typically occurring as a groundmass phase. Groundmass spinel are small (ranging from 5 to $50 \mu \mathrm{m}$; up to $1.5 \mathrm{~mm}$ ), euhedral to subhedral crystals or masses crystals that exhibit a diversity in their habit and texture unique to kimberlites. Atoll-spinel (Mitchell, 1986) occur throughout and contain an euhedral to subhedral core $(1-25 \mu \mathrm{m})$ of chromite, magnetite or ulvöspinel separated by a gap $(1-10 \mu \mathrm{m})$, surrounded by a narrow rim $(1-5 \mu \mathrm{m})$ (usually magnetite) that forms the outer reef or margin. Multiple disconnected parallel rims typically occur around small central spinel cores. Crspinel are uncommon with magnesian ulvöspinelulvöspinel-magnetite (MUM) spinel occuring throughout the McLean pipe. Altered Cr-spinel grains occur at the erosional surface and close to the kimberlite-sediment contact. Small, less altered $\mathrm{Cr}-$ spinels occur at moderate depths in the hypabyssal facies.

\section{APATITE}

Apatite is abundant throughout the groundmass in the hypabyssal facies and less common in the diatreme facies of the McLean kimberlite. Apatite has many habits occurring as elongated prisms or stubby, spearshaped crystals with 'hollow-cores' or partial cores, similar to those described by Wagner (1914). The hollow-core or 'skeletal' crystals contain an inner core (20 to $40 \mu \mathrm{m}$ ) containing either apatite or an unresolvable mixture of serpentine and Fe-oxide with an outer rim of apatite (5 to $15 \mu \mathrm{m}$ ). Euhedral apatite occurs in the McLean kimberlite in areas that are particularly calcite-serpentine rich. Apatite as euhedral or anhedral crystals and radiating sprays of acicular crystals which appear to have nucleated at the margins of irregular calcite segregations. Apatite inclusions are rare but contained within serpentinized olivine microcrysts.

Apatite occurring near the contact zone between the McLean kimberlite and Firstbrook Member are smaller $(<50 \mu \mathrm{m})$ in comparison to those from the kimberlite. Contact zone apatite are relatively well-formed, euhedral to subhedral, unzoned crystals associated with calcite veinlets enriched in barite-celestite. These crystals appear slightly rounded to hexagonal with proximity to the contact zone.

\section{PEROVSKITE}

Perovskite is well preserved throughout the McLean pipe. It occurs in various habits throughout the pipe, small $(10$ to $100 \mu \mathrm{m})$ discrete euhedral crystals or slightly rounded fragments of perovskite are common. Microcrysts contain thick mantles of Ti-oxide $(>10 \mu \mathrm{m})$ with few altered grains replaced by $\mathrm{TiO} 2$. Secondary perovskite occurs within cores of altered groundmass atoll-spinels (and occasionally associated with altered ilmenite grains). Low amounts of secondary perovskite occur near the contact zone but with little change in its chemistry or morphology.

\section{MINERAL CHEMISTRY}

\section{MCLEAN KIMBERLITE}

Microprobe analyses results (Hodder, 2002) show that the McLean kimberlite contains olivines with high amounts of $\mathrm{MgO}$ and $\mathrm{FeOT}$ (total iron) and relatively low $\mathrm{MnO}, \mathrm{NiO}$ and $\mathrm{TiO} 2$. Contents of $\mathrm{FeOT}$ ranges from 8.83 to 10.93 wt. $\%, \mathrm{MgO}$ ranges from 48.03 to 50.55 wt. $\%$, $\mathrm{MnO}$ ranges from 0.09 to $0.15 \mathrm{wt} . \%$, NiO 
ranges from 0.34 to 0.44 wt. $\%$ and $\mathrm{TiO} 2$ ranges from 0.00 to 0.04 wt.\%. Forsterite content ranges from Fo89 to Fo91. Olivine from the McLean is characterized by low $\mathrm{Cr}(<0.09$ wt.\% Cr2O3) with no evidence of a correlation between $\mathrm{Ni}$ and $\mathrm{Cr}$ in the groundmassmicrocrystic suite.

Phlogopite exhibited high to moderate concentrations of $\mathrm{Al}, \mathrm{Mg}$ and $\mathrm{Ba}$ with low to moderate $\mathrm{K}, \mathrm{Sr}$, Ti and very low $\mathrm{Ca}, \mathrm{Cr}$ and $\mathrm{F}$. A12O3 ranges from 12.56 to 21.58 wt. $\%$ oxide, $\mathrm{MgO}$ ranges from 23.96 to $28.51 \mathrm{wt} \% \%$ and $\mathrm{BaO}$ ranges from 0.07 to 17.66 wt. $\%$. K2O ranges from 4.33 to 11.17 wt.\%), $\mathrm{TiO} 2$ ranges from 0.01 to 0.57 wt.\% and FeOT ranges from 1.33 to 4.19 wt. $\%$

Ilmenite in the McLean kimberlite contains oxide concentrations of the following: $\mathrm{TiO} 2$ from 49.08 to 56.69 wt. $\%$, FeO from 18.45 to 46.35 wt. $\%, \mathrm{MgO}$ from 0.04 to 20.20 wt. $\%$, MnO from 0.27 to 3.11 wt. $\%$ and $\mathrm{Cr} 2 \mathrm{O} 3<<2.5$ wt.\%. Geikielite analysis results in $\mathrm{TiO} 2$ $=67.76$ wt. $\%, \mathrm{FeO}=15.88$ wt. $\%, \mathrm{MgO}=12.41$ wt. $\%$, $\mathrm{MnO}=0.17$ wt. $\%$ and $\mathrm{Cr} 2 \mathrm{O} 3=2.18$ wt. $\%$.

MUM spinel are generally high in FeOT and variable concentrations of $\mathrm{Mg}$. Fe2O3 ranges from 8.10 to 73.17 wt. $\%$, $\mathrm{FeO}$ from 6.18 to 73.96 wt. $\%, \mathrm{MgO}$ ranges from 0.04 to 15.62 wt.\%, $\mathrm{Cr} 2 \mathrm{O} 30.00$ to 50.33 wt.\%. Crspinel contain moderate to low iron with low $\mathrm{MgO}$.

Apatite analyses of total REE's (La, Ce, Pr, Nd, Sm, Gd; plus LILE's $\mathrm{Ba}$ and $\mathrm{Sr}$ ) are relatively high within the kimberlite concentrations ranging from 0.29 to 1.97 (REE)2O3 wt.\%. Apatite analyses from the contact zone display low REE concentrations and minor progression into the sediments of the Firstbook Member.

Perovskite contain 6.84 to 9.82 wt.\% (REE)2O3, $<0.87$ wt.\% Na2O, <0.23 wt.\% SrO. Total REE's (plus Sr) average 8.34 wt.\% (REE) $2 \mathrm{O} 3$ and typically contain low Ta2O3 (typically $<0.25$ wt.\%) and high Ce2O3 $(>2.48$ wt. \%).

\section{CONTACT ZONE}

Whole rock analyses across the contact between the McLean kimberlite and Firstbrook Member were derived from surface samples. Samples were collected across a $98 \mathrm{~cm}$ horizontal section, $20 \mathrm{~m}$ from the contact, and from GSC pit samples 1, 6 and 8. Samples were also collected at irregular intervals from the contact (to $30 \mathrm{~cm}$ ) into the Firstbrook Member sedimentary rock. Similarly, samples for bulk analyses were obtained from the contact to $68 \mathrm{~cm}$ from the contact into the McLean kimberlite.

Whole rock analyses of kimberlite indicate characteristic low silicon contents. $\mathrm{SiO} 2$ concentrations range from 24.38 to $26.00 \mathrm{wt} \%$, FeOT contents are approximately 11 wt.\%, MgO approximately 25 wt.\%, $\mathrm{CaO}<14.92$ wt.\% and $\mathrm{P} 2 \mathrm{O} 5$ range from 1.67 to 2.05 wt.\%. Typically $\mathrm{TiO} 2<1.70$ wt. $\%$, Al2O3 $<2.56$ wt.\%, $\mathrm{MnO}=0.20$ wt. $\%, \mathrm{Na} 2 \mathrm{O}<0.25$ wt. $\%$, and $\mathrm{K} 2 \mathrm{O}$ concentrations are $<0.25$ wt. $\%$ but increase slightly (0.01 to 0.10 wt.\%) near the contact zone. REE's and other large element ions (such as $\mathrm{Ba}$ and $\mathrm{Sr}$ ) concentrations are variable near the contact. Trace element and REE mobility within the kimberlite are low across the contact indicated by the limited progression of $\mathrm{Ni}, \mathrm{Ba}, \mathrm{Sr}, \mathrm{Nb}, \mathrm{Ta}, \mathrm{La}, \mathrm{Ce}$, and $\mathrm{Pr}$ concentrations (Hodder, 2002).

\section{DISCUSSION AND CONCLUSIONS}

Olivine is present throughout the McLean with high foresterite content. Garnet is a typical kimberlite (diamond) indicator mineral but was not evident in thin section for this study. Previous studies (McClenaghan et al., 1999; Sage, 1996) show garnet in till samples with low $\mathrm{Cr}$ and $\mathrm{Mg}$.

Phlogopite shows a variability in its $\mathrm{K}$ and $\mathrm{Ba}$ which is likely to have occurred during or shortly after emplacement of the kimberlite. Hydrothermal alteration processes in the local area (Easton, 2000) may have remobilized these elements $(\mathrm{Ba}, \pm \mathrm{Al})$ enhancing the $\mathrm{BaO}$ rich rims (kinoshitalite) with phlogopite cores remaining unaltered. The Ba-enrichment or zonation trend (phlogopite-kinoshitalite) is present in other kimberlites worldwide (Mitchell, 1995).

Groundmass and microcrystic ilmenite are low in $\mathrm{MgO}$ (1-2 wt.\%) throughout the pipe. Ilmenite with geikeilite-rich rims occur within both the diatreme and hypabyssal facies. Ilmenite located at deeper portions within the pipe contained slightly higher $\mathrm{MgO}$ contents in comparison to the aphanitic cap. $\mathrm{MgO}$ and $\mathrm{Cr} 2 \mathrm{O} 3$ contents of ilmenite are generally low in the McLean pipe suggesting it formed in an oxidizing environment. This environment is generally not considered conducive to diamond preservation.

Spinel contain moderate to low amounts of $\mathrm{MgO}$ and low $\mathrm{Cr} 2 \mathrm{O} 3$. The diamond inclusion field ranges from 8 to 18 wt. $\% \mathrm{MgO}$ and 60 to 75 wt.\% Cr2O3 (Fipke et al., 1995). Data indicates that these spinel do not 
contain sufficient $\mathrm{MgO}$ to be contained within the diamond inclusion field for spinel. However, chromite analyzed in the work of Sage $(1996,2000)$ and McClenaghan et al. (1999) range from 5-15 wt.\% $\mathrm{MgO}$ and 35-62 wt.\% Cr2O3, within the typical range for kimberlites worldwide. A single chromite in Sage (2000) contains 12.5 wt.\% $\mathrm{MgO}$ and 62.5 wt.\% Cr2O3, within the known field of chromite diamond inclusions. Two additional chromite grains contain 62 wt. \% Cr2O3 and elevated $\mathrm{MgO}$ contents, plotting in the diamond intergrowth field.

Based on the mineral chemistry of the mineral suite for the McLean pipe, it was determined that the McLean exhibits Group I kimberlite chemical characteristics similar to those outlined by Mitchell $(1986 ; 1995)$ and correlates with the present accepted definition for kimberlite in Woolley et al. (1996). It therefore may be classified as a kimberlite. Analyses of $\mathrm{Cr}$ and $\mathrm{Mg}$ within ilmenite and spinel suggest a low economic potential for the McLean kimberlite. Additionally, the effects of contact metamorphism and progression of REE's from the McLean kimberlite into the Firstbrook Member appear to be negligible.

\section{ACKNOWLEDGEMENTS}

Dr. Terence Gordon of the University of Calgary and Dr. Bruce Kjarsgaard of the Department of Natural Resources, Ottawa are thanked for their supervision of thesis work. Ron Sage (OGS) and Beth McClenaghan (GSC) are thanked for providing samples, access to data and maps for this study. Chemical analyses and field studies were assisted by an NSERC grant and the Geological Survey of Canada (Ottawa). The University of British Columbia and the University of Calgary are thanked for technical assistance during electron microprobe analyses; the Geological Survey of Canada (Calgary) is thanked for providing access to their SEM facilities for preliminary observations and semiquantitative analyses.

\section{REFERENCES}

Easton, R. Michael, 2000. Metamorphism of the Canadian Shield, Ontario, Canada. II Proterozoic Metamorphic History. In Tectonometamorphic Studies of the Canadian Shield (Part II). R.G. Bergman, R.M. Easton, and R.F. Martin (editors). The Canadian Mineralogist. Vol.38. 319-344p.

Fipke, C.E., J.J. Gurney and R.O. Moore, 1995. Diamond Exploration Techniques Emphasizing Indicator
Mineral Geochemistry and Canadian Examples. Natural Resources Canada. Geological Survey of Canada. Bulletin 423.

Heaman, L.M., and B.A. Kjarsgaard. 2000. Timing of Eastern North American kimberlite magmatism: continental extension of the Great Meteor hotspot track? Earth and Planetary Science Letters. No.178. 253-268p.

Hodder, Sherri L., 2002. Petrography and Mineral Chemistry of the McLean and Peddie Kimberlites, Lake Timiskaming, Ontario, Canada. M.Sc. Thesis. Department of Geology and Geophysics. University of Calgary. Canada.

McClenaghan, M.B., B.A. Kjarsgaard, I.M. Kjarsgaard, R.C. Paulen and J.A.R. Stirling. 1999. Mineralogy and geochemistry of the Peddie kimberlite and associated glacial sediments, Lake Timiskaming, Ontario. Geological Survey of Canada. Open File 3775.

Mitchell, R.H., 1986. Kimberlites:Mineralogy, Geochemistry, and Petrology. Plenum Press, New York, $442 \mathrm{p}$.

Mitchell, R.H., 1995. Kimberlites, Orangeites and Related Rocks. Plenum Press, New York, 410p.

Sage, R.P. 1996. Kimberlites of the Lake Timiskaming Structural Zone. Ontario Geological Survey. Open File Report 5937. 435p.

Sage, R.P., 2000. Kimberlites of the Lake Timiskaming Structural Zone: Supplement. Ontario Geological Survey. Open File Report 6018. $123 \mathrm{p}$.

Wagner, P.A. 1914. The Diamond Fields of South Africa. Transvaal Leader. Johannesburg, South Africa.

Woolley, A.R., S.C. Bergman, A.D. Edgar, M.J. LeBas, R.H. Mitchell, N.M.S. Rock, and B.H. Scott Smith. 1996. Classification of lamprophyres, lamproites, kimberlites, and the kalsilitic, melilitic, and leucitic bearing rocks. Alkaline Rocks: Petrology and Mineralogy. R.H. Mitchell, G.N. Eby and R.F. Martin (editors). The Canadian Mineralogist. Vol. 34. Part 2. 175-186

Contact: Sherri Hodder, P.O. Box 81096, Calgary, Alberta, Canada, T2J 0N0. Fax: (403) 201-0550, email:

kimberlite.pet@shaw.ca 